\title{
A Financial Analysis Case Of Amazon.Com And Barnes \& Noble With Emphasis On The Impact Of ROE Versus EPS: Accounting Case And Instructor Notes
}

Timothy Kelley, University of San Diego, USA

Judith A. Hora, University of San Diego, USA

Loren Margheim, University of San Diego, USA

\begin{abstract}
This case follows two accounting interns working for a not-for-profit organization who have been asked to perform a financial analysis of two real life companies (Amazon.com and Barnes \&Noble). The interns have been asked to assist the organization with a financial statement analysis of the companies in order to help the not-for-profit make an important investment decision. The case requires the students to perform some simple ratio analyses, with a particular emphasis on how to utilize Return on Equity (ROE) and Earnings per Share (EPS) information when those values appear to provide contradictory information. In particular, one of the primary goals of this case study is to have students discover how one company (Amazon.com) can have a greater ROE, even though the competitor (Barnes \& Noble) has a larger EPS and how this seemingly contradictory information should be used in financial analysis. Students will have the opportunity to consider which metric (ROE or EPS) is safe to use in cross-company comparisons and will use that analysis, in conjunction with other basic ratios, to provide a financial analysis report comparing the two companies. The case is appropriate for beginning financial accounting classes and intermediate accounting.
\end{abstract}

Keywords: Return on Equity, ROE, Earnings per Share, EPS, Financial Statement Analysis

\section{INTRODUCTION}

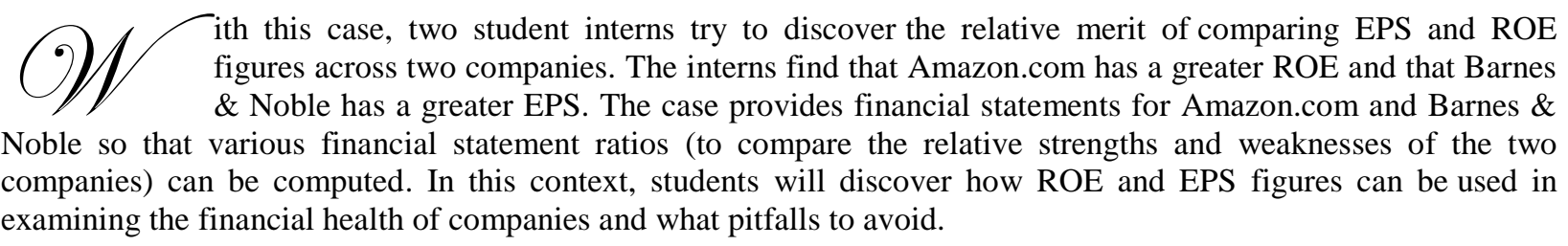

\section{THE CASE}

Suzy Caldwell was thrilled when she was selected for an accounting internship position with Saint Francis Orphanage for the upcoming semester. Although the position was unpaid, Suzy liked the fact that she would be giving back to the community. In addition, the position would allow her to work with employees from a Big 4 accounting firm that does a considerable amount of pro bono work for the orphanage.

Suzy learned that another student, Jose Gomez, who attended a neighboring university, would also be working with her as an intern at Saint Francis. Both Jose and Suzy have completed three years of college as accounting majors and are eager to apply some of their accounting knowledge in the "real world." 
Sister Loreta has been the director of Saint Francis for several years. She looked forward to working with her two new interns and wanted them to work on projects that would benefit the orphanage and challenge the students. One investment related project that Sister Loreta wanted Suzy and Jose to get started on immediately would likely lead to her interns getting the chance to make a presentation to the orphanage's Board of Trustees.

First some facts about Saint Francis before we look into the project that Sister Loreta has in mind for her interns. Saint Francis Orphanage was founded 125 years ago and has 90 beds for teenage girls who are not orphans in the literal sense, but are "orphans of the living." Teenagers can be placed in Saint Francis by social workers to remove them from bad situations, such as living with parents who are drug addicts and abusive. Saint Francis receives about $75 \%$ of its funding from federal, state, and county government sources and about $25 \%$ of its funding from the United Way and generous donors in the community. The orphanage has a restricted endowment of $\$ 30$ million that, until recently, was completely managed by an investment firm. Sister Loreta was concerned that the investment firm was charging too much for its services, so she decided to move half of the endowment into a low cost Standard \& Poor's 500 index fund and invest the other half in a variety of large blue-chip stocks with a discount broker. The Board of Trustees of the orphanage meets quarterly, and one of its ongoing agenda items is to look at the performance of the investments in the restricted fund.

The orphanage recently received a generous restricted gift of $\$ 200,000$. Sister Loreta plans on investing half of the money in the index fund and the other half in the common stock of either Amazon.com or Barnes \& Noble, neither of which are currently part of the actively managed part of the orphanage's portfolio.

Sister Loreta (while no expert in the stock market) has earned advanced degrees in social work and theology and she has the savvy people skills that have catapulted her into running a multi-million dollar charitable enterprise. She loves working with the local college interns. They are always bright, enthusiastic and eager to learn!

Sister Loreta wants Suzy and Jose to perform a financial analysis on both Amazon.com and Barnes \& Noble and to report back to her with a recommendation about which company to invest in and why. After reporting to her, Sister Loreta would like the students to make a formal presentation to the Board of Trustees. She thinks that this will be an excellent speaking experience for the students.

Sister Loreta wants Suzy and Jose to emphasize one thing as they research Amazon.com and Barnes \& Noble, namely, when looking at some of the financial ratios that her discount broker provided, she noticed that during the last two years Amazon.com has had a higher Return on Equity (ROE) than Barnes \& Noble and that Barnes \& Noble has had a higher Earnings per Share (EPS) than Amazon.com. The ROE and EPS values that the broker provided for both companies are shown in Table 1 for Fiscal 2007 (the most recent annual report data available at the time Suzy and Jose did their research) and Table 2 for Fiscal 2006. Sister Loreta is confused about how the ROE versus EPS pattern shown for both Fiscal 2007 and 2006 could exist and whether one of these ratios is a better indicator of profitability than the other. Sister Loreta often wishes that she could work towards an MBA at one of the local universities, but unfortunately she has little "free time" while running Saint Francis to pursue another advanced degree.

Note that Table 1 shows that in fiscal year 2007 Barnes \& Noble posted a greater earnings per share (EPS) than Amazon.com (\$2.03 versus \$1.12), while in this same year Amazon.com earned a greater return on equity (ROE) than Barnes \& Noble (39.8\% versus 12.7\%). This was the pattern that had puzzled Sister Loreta and Table 2 shows that the same pattern existed in the 2006 Fiscal Year.

Table 1: 2007 EPS and ROE Ratios for Amazon.com and Barnes \& Noble

\begin{tabular}{|l|c|c|}
\hline \multicolumn{1}{|c|}{ Ratio } & Amazon.com & Barnes \& Noble \\
\hline Earnings Per Share (EPS) & $\$ 1.12$ & $\$ 2.03$ \\
\hline Return on Equity (ROE) & $39.8 \%$ & $12.7 \%$ \\
\hline
\end{tabular}


Table 2: 2006 EPS and ROE Ratios for Amazon.com and Barnes \& Noble

\begin{tabular}{|l|c|c|}
\hline \multicolumn{1}{|c|}{ Ratio } & Amazon.com & Barnes \& Noble \\
\hline Earnings Per Share (EPS) & $\$ 0.45$ & $\$ 2.17$ \\
\hline Return on Equity (ROE) & $56.1 \%$ & $13.2 \%$ \\
\hline
\end{tabular}

On the first day of their internships, Suzy and Jose met with Sister Loreta and discussed the financial analysis project she had planned for them. At the meeting, it was decided that Suzy would research Amazon.com and Jose would research Barnes \& Noble and then they would combine their research into a single report. Suzy and Jose picked several profitability, solvency, and market value related ratios that they believed would help them with their analyses (based on the accounting and finance classes they have taken) and would help supplement the EPS and ROE values that had been received from the broker. Both Suzy and Jose believe that reviewing additional financial analysis ratios will help them to better analyze the two companies and will help them understand why the Amazon.com and Barnes \& Noble EPS and ROE ratios seem to be "out of kilter."

Knowing that financial analysts often fixate on EPS numbers, they decided to plot out the EPS figures and other Income Statement data for Amazon.com and Barnes \& Noble over the last 5 years. Table 3 below shows the results of this data gathering.

Table 3: Selected Income Statement Data for Amazon.com and Barnes \& Noble (2003-2007) (Amounts in Millions-Except for Per Share Data)

Amazon.com:

\begin{tabular}{|l|c|c|c|c|c|}
\hline & $\mathbf{2 0 0 7}$ & $\mathbf{2 0 0 6}$ & $\mathbf{2 0 0 5}$ & $\mathbf{2 0 0 4}$ & $\mathbf{2 0 0 3}$ \\
\hline Sales & $\$ 14,835$ & $\$ 10,711$ & $\$ 8,490$ & $\$ 6,921$ & $\$ 5,623$ \\
\hline Net Income & 476 & 190 & 359 & 588 & 35 \\
\hline EPS (diluted) & $\$ 1.12$ & $\$ 0.45$ & $\$ 0.84$ & $\$ 1.39$ & $\$ .08$ \\
\hline
\end{tabular}

\section{Barnes \& Noble:}

\begin{tabular}{|l|c|c|c|c|c|}
\hline & $\mathbf{2 0 0 7}$ & $\mathbf{2 0 0 6}$ & $\mathbf{2 0 0 5}$ & $\mathbf{2 0 0 4}$ & $\mathbf{2 0 0 3}$ \\
\hline Sales & $\$ 5,411$ & $\$ 5,261$ & $\$ 5,103$ & $\$ 4,874$ & $\$ 4,372$ \\
\hline Net Income & 136 & 151 & 147 & 143 & 152 \\
\hline EPS (diluted) & $\$ 2.03$ & $\$ 2.17$ & $\$ 2.03$ & $\$ 1.93$ & $\$ 2.07$ \\
\hline
\end{tabular}

Suzy and Jose note that Amazon.com has experienced strong growth in both sales and earnings. By contrast, it appeared to them that sales growth with Barnes \& Noble was modest and earnings have not grown at all over the last 5 years. Still, they take note that Barnes \& Noble in 2007 has an EPS of $\$ 2.03$ which is almost twice as much as Amazon.com at $\$ 1.12$.

Suzy and Jose looked up the 2007 fiscal year end stock prices for both companies using yahoo.finance.com. They determined that the stock price for Amazon.com was $\$ 92.64$ on December 31, 2007 and the stock price for Barnes \& Noble was $\$ 32.73$ on February 2, 2008 (the end of each company's 2007 fiscal year). Suzy and Jose plan to use these fiscal year end stock prices to compute each company's price to earnings $(\mathrm{P} / \mathrm{E})$ ratio.

Additionally, to help in the preparation of their financial ratios and to get a better handle on the relative performance of Amazon.com and Barnes \& Noble, Suzy and Jose prepared abbreviated comparative financial statements for the two companies. Specifically, they created comparative Income Statements, Balance Sheets, and Statements of Cash Flows for fiscal 2007 for the two companies. These are shown in Tables 4-6.

Note that Amazon.com's financial statements are for the year ended December 31, 2007 and Barnes \& Noble's financials are for the year ended February 2, 2008. For the comparative Income Statements, Suzy and Jose performed a vertical analysis setting the sales for each company at $100.0 \%$ (see Table 4 below). Additionally, they performed a vertical analysis of the comparative company balance sheets (see Table 5 below). Finally, they compared the relative cash flows of the two companies during 2007 (see Table 6 below). 
Table 4: Fiscal 2007 Income Statements for Amazon.com and Barnes \& Noble (Amounts in Millions)

\begin{tabular}{|l|c|c|c|c|}
\hline & Amazon.com & & Barnes \& Noble & \\
\hline Sales & $\$ 14,835$ & $100.0 \%$ & $\$ 5,411$ & $100.0 \%$ \\
\hline Total Expenses & 14,359 & $96.8 \%$ & 5,275 & $97.5 \%$ \\
\hline Net Income & $\mathbf{\$ 4 7 6}$ & $\mathbf{3 . 2 \%}$ & $\mathbf{\$ 1 3 6}$ & $\mathbf{2 . 5 \%}$ \\
\hline
\end{tabular}

Table 5: Fiscal 2007 Balance Sheets for Amazon.com and Barnes \& Noble (Amounts in Millions)

\begin{tabular}{|l|c|c|c|c|}
\hline & Amazon.com & & Barnes \& Noble & \\
\hline Current Assets & $\$ 5,164$ & $79.6 \%$ & $\$ 1,922$ & $59.1 \%$ \\
\hline Noncurrent Assets & 1,321 & $20.4 \%$ & 1,328 & $40.9 \%$ \\
\hline Total Assets & $\mathbf{\$ 6 , 4 8 5}$ & $\mathbf{1 0 0 . 0 \%}$ & $\mathbf{\$ 3 , 2 5 0}$ & $\mathbf{1 0 0 . 0 \%}$ \\
\hline
\end{tabular}

\begin{tabular}{|l|c|c|c|c|}
\hline & Amazon.com & & Barnes \& Noble & \\
\hline Current Liabilities & $\$ 3,714$ & $57.3 \%$ & $\$ 1,590$ & $48.9 \%$ \\
\hline Noncurrent Liabilities & 1,574 & $24.3 \%$ & 585 & $18.0 \%$ \\
\hline Total Liabilities & $\mathbf{\$ 5 , 2 8 8}$ & $\mathbf{8 1 . 6 \%}$ & $\mathbf{\$ 2 , 1 7 5}$ & $\mathbf{6 6 . 9 \%}$ \\
\hline Stockholders' Equity & $\mathbf{1 , 1 9 7}$ & $\mathbf{1 8 . 4 \%}$ & $\mathbf{1 , 0 7 5}$ & $\mathbf{3 3 . 1 \%}$ \\
\hline $\begin{array}{l}\text { Total Liabilities and } \\
\text { Stockholders' Equity }\end{array}$ & $\mathbf{\$ 6 , 4 8 5}$ & $\mathbf{1 0 0 . 0 \%}$ & $\mathbf{\$ 3 , 2 5 0}$ & $\mathbf{1 0 0 . 0 \%}$ \\
\hline
\end{tabular}

Table 6: Fiscal 2007 Statements of Cash Flows for Amazon.com and Barnes \& Noble (Amounts in Millions)

\begin{tabular}{|l|c|c|}
\hline & Amazon.com & Barnes \& Noble \\
\hline Net Cash Flows from Operating Activities & $\$ 1,405$ & $(181)$ \\
\hline Net Cash Flows from Investing Activities & 42 & $(242)$ \\
\hline Net Cash Flows from Financing Activities & 50 & 0 \\
\hline Foreign-Currency Impact on Cash & 20 & $\mathbf{\$ 1 2}$ \\
\hline Net Increase in Cash & $\mathbf{\$ 1 , 5 1 7}$ & 349 \\
\hline Add: Beginning Cash (and Cash Equivalents) & 1,022 & $\mathbf{\$ 3 6 1}$ \\
\hline Ending Cash (and Cash Equivalents) & $\mathbf{\$ 2 , 5 3 9}$ & \\
\hline
\end{tabular}

\section{CASE QUESTIONS}

1. Please take the roles of the two interns. To begin, compute the following ratios for Fiscal 2007 from the condensed financials to supplement the ROE and EPS ratios already received from the broker:

Profitability Ratios: Profit Margin Ratio, Asset Turnover Ratio, and the Leverage Ratio.

Solvency Ratios: Cash Debt Coverage Ratio, Current Ratio, and the Debt to Assets Ratio.

Fair Market Value Ratio: Price Earnings Ratio

2. Prepare a brief explanation of how it is possible for Amazon.com to have a greater ROE while Barnes \& Noble has a larger EPS.

3. Is it reasonable to compare ROE ratios across companies? Is it reasonable to compare EPS ratios across companies? Which of these two ratios should Suzy and Jose emphasize in their financial analysis? Explain your reasoning.

4. Utilizing your discussion comparing the appropriate usage of EPS and ROE in the prior two questions and the additional ratios computed in the first question, prepare a brief financial analysis report discussing the strengths and weaknesses of Amazon.com versus Barnes \& Noble as of the end of Fiscal $2007 . \quad$ It would be useful if your report specifically addressed profitability, solvency, and fair value ratios in separate sections. 
In addition to the ratios discussed above, you should read the Management's Discussion and Analysis (MD\&A) sections in the 2007 annual reports of Amazon.com and Barnes \& Noble. These annual reports can be found by clicking on "Investor Relations" in the Amazon.com and Barnes \& Noble web sites or by going to the following:

For Amazon.com: http://media.corporate-ir.net/media_files/irol/97/97664/2007AR.pdf

For Barnes \& Noble: http://www.barnesandnobleinc.com/for_investors/annual_reports/Barnes_\%26_Noble_2007_Annual_Repo $\underline{\text { rt.pdf }}$

The conclusion of your report should clearly indicate which company you believe is a better investment as of the end of fiscal 2007 and should include a clear discussion of how the contradictory ROE and EPS information from the two companies impacted your conclusion.

\section{INSTRUCTOR NOTES}

The purpose of this case is to have students perform a basic financial analysis comparing two real life companies (Amazon.com and Barnes \& Noble) where a strong emphasis is placed on understanding how ROE and EPS impacts the analysis. Amazon.com and Barnes \& Noble were chosen for use in this case because their calculated ROE and EPS values seem to provide contradictory information about the relative profitability of the two companies. Upon completion of this case, students should be able to perform and understand basic ratio analysis and should have a clear understanding of how ROE and EPS should be used. The case requires students to complete four questions. A discussion of how each of these questions should be responded to by the students is shown below.

1. Please take the roles of the two interns. To begin, compute the following ratios for Fiscal 2007 from the condensed financials to supplement the ROE and EPS ratios already received from the broker:

Profitability Ratios: Profit Margin Ratio, Asset Turnover Ratio, and the Leverage Ratio.

Solvency Ratios: Cash Debt Coverage Ratio, Current Ratio, and the Debt to Assets Ratio.

Fair Market Value Ratio: Price Earnings Ratio.

Students should be able to compute all the listed ratios using the abbreviated financial statements in the case. The correct values are shown in the Table 7. Should the instructor wish to only emphasize the analysis of ratios (rather than computation), the following table with the completed ratios can be supplied to the students and Question 1 (in the case) could be deleted.

2. Prepare a brief explanation of how it is possible for Amazon.com to have a greater ROE while Barnes \& Noble has a larger EPS.

Students should be able to note that both the ROE and EPS ratios similarly reflect profits in the numerator, either as total net income (for ROE) or as net income per share (for EPS). On the other hand, these two ratios have quite different approaches to measuring the extent of stockholder investment in a corporation. ROE uses the dollar amount of stockholders' equity (excluding claims by preferred shareholders), while EPS uses the number of common shares outstanding (with the number of common shares outstanding being arbitrary for any company relative to the amount of its stockholders' equity expressed in dollars.) Students should be able to note that a company with a fairly large ROE may still have a rather modest EPS if the company has an unusually large number of common shares outstanding. On the other hand, a company with a modest ROE could show a relatively large EPS if the company chooses to have an unusually low number of common shares outstanding. With this pattern noted, students can point out that it is not really that unusual for one company (Amazon.com in this case) to have a greater ROE and another company (Barnes \& Noble) to have a greater EPS. 
Table 7

Amazon.com versus Barnes \& Noble-2007 Financial Ratio Calculations

(Amounts in millions--except per share amounts)

\section{Profitability Ratios:}

Return on Equity:

Net Income

Stockholders' Equity

Profit Margin Ratio:

Net Income

Sales

$\begin{array}{cc}\frac{\text { Amazon }}{\mathbf{3 9 . 8 \%} \%} & \frac{\text { B \& N }}{\mathbf{1 2 . 7 \%}} \\ \frac{476}{1,197} & \underline{136} \\ \mathbf{3 . 2 \%} & 1,075 \\ \frac{476}{14,835} & \mathbf{2 . 5 \%} \\ & \underline{136}\end{array}$

Asset Turnover Ratio:

2.3

Sales

$\underline{14,835}$

1.7

Total Assets

6,485

$\underline{5,411}$

Leverage Ratio:

$5.4 \quad 3.0$

Total Assets

Stockholders' Equity

$\underline{6,485}$

$\underline{3,250}$

1,197

1,075

\section{Solvency Ratios:}

\section{Cash Debt Coverage Ratio:}

Cash Provided by Operations

Total Liabilities

$\begin{array}{cc}\text { Amazon } & \text { B \& N } \\ \mathbf{2 6 . 6 \%} & \mathbf{2 0 . 0 \%} \\ \frac{1,405}{5,288} & \frac{435}{2,175} \\ \mathbf{1 . 3 9} & \mathbf{1 . 2 1} \\ \underline{5,164} & \underline{1,922} \\ 3,714 & 1,590 \\ \mathbf{8 1 . 5 \%} & \mathbf{6 6 . 9 \%} \\ \underline{5,288} & \underline{2,175} \\ 6,485 & 3,250\end{array}$

Total Liabilities

Total Assets

$\frac{5,288}{6,485}$

$\underline{2,175}$

III. Fair Market Value Ratio:

P/E Ratio:

Fair Market Value/Share EPS (Diluted)

$\begin{array}{cc}\frac{\text { Amazon }}{\mathbf{8 2 . 7}} & \frac{\text { B \& N }}{\mathbf{1 6 . 1}} \\ \frac{92.64}{1.12} & \frac{32.73}{2.03}\end{array}$

Note: The Fiscal Year End for Amazon.com is December 31, 2007, while the Fiscal Year End for Barnes \& Noble is February 2, 2008.

3. Is it reasonable to compare ROE ratios across companies? Is it reasonable to compare EPS ratios across companies? Which of these two ratios should Suzy and Jose emphasize in their financial analysis? Explain your reasoning. 
Students will hopefully have already noted (when answering Question 2) that the number of common shares outstanding is arbitrary for companies. Given the arbitrary number of common shares for companies, EPS comparisons across companies can be seen to be meaningless. ${ }^{1}$ On the other hand, we hope that students will note that ROE figures can be compared across companies since both the numerator and denominator of this ratio are expressed in dollar terms and are thus not impacted by the arbitrary number of common shares outstanding. With this in mind, Suzy and Jose should focus more on ROE (instead of EPS) in comparing Amazon.com versus Barnes \& Noble.

Professors may wish to provide students with a numerical example to demonstrate that ROE comparisons across companies are valid, while EPS comparisons are not. Below we show an example that can be used to supplement in-class discussion concerned with the relative usefulness of ROE and EPS figures when making comparisons across companies.

\section{Example--ROE versus EPS in Cross-Company Comparisons}

In Year 1, assume that Company A had $\$ 2,500,000$ in net income and 1,000,000 common shares outstanding, for $\$ 2.50$ in EPS. In the same year, assume that Company B had \$1,500,000 in net income and 200,000 common shares outstanding, for $\$ 7.50$ in EPS. Should we be impressed with Company B's larger EPS? Not necessarily. We need more information!

Specifically, we need to know the amount of stockholders' equity for both companies in order to determine each company's ROE. If the stockholders' equity for Company A was $\$ 10,000,000$, and the stockholders' equity for Company B was $\$ 30,000,000$, Company A has earned an impressive ROE of 25\% (\$2,500,000 net income divided by $\$ 10,000,000$ in stockholders' equity), while Company B has earned an unimpressive ROE of 5\% (\$1,500,000 net income divided by $\$ 30,000,000$ in stockholders' equity). How can Company A have one-third the EPS of Company $\mathrm{B}$ and at the same time have a ROE five times greater than Company B?

The answer is that each company has a significantly different book value per share. While Company A has a book value per share of $\$ 10$ ( $\$ 10,000,000$ stockholders' equity $/ 1,000,000$ common shares outstanding), Company B has a book value per share of $\$ 150$ ( $\$ 30,000,000$ stockholders' equity/200,000 common shares outstanding). See the reconciliation of EPS, book value per share, and ROE below that shows that ROE multiplied by book value per share equals EPS.

\begin{tabular}{|l|c|c|c|c|c|}
\hline & Reconciliation of ROE to EPS & EPS \\
\hline & ROE & $*$ & Book Value/Share & $=$ & $\frac{\text { Net Income }}{\# \text { of shares }}$ \\
\hline Company A & Stockholders' Equity & & $\frac{\text { Stockholders' Equity }}{\# \text { of shares }}$ & $=$ & $\$ 2.50$ \\
\hline Company B & $25 \%$ & $*$ & $\$ 10$ & $=$ & $=$ \\
\hline
\end{tabular}

\footnotetext{
${ }^{1}$ Some textbooks like Stickney and Weil (2010), Easton, Wild, and Halsey (2006), Dyckman, Easton, and Pfeiffer (2007), and Kimmel, Weygandt, and Kieso (2009) do a good job reminding students not to compare EPS figures across companies. For example, Kimmel et al. (2009, page 692) argues that EPS comparisons across companies "are not meaningful because of the wide variations in the number of shares of outstanding stock among companies." On the other hand, other textbooks such as Harrison, Horngren and Thomas (2010) and Needles and Powers (2007) present a murkier picture and seem to suggest that EPS comparisons across companies are meaningful. For example, Harrison et al. (2010, page 493) assert that, "EPS is the single most important statistic for evaluating companies because EPS is a standard measure of operating performance that applies to companies of different sizes and from different industries." Hopefully, in the future, all textbooks will present a clearer picture on this topic, so that students can readily see that cross-company EPS comparisons are to be avoided. (See Kelley and Hora (2008) for a review on how financial accounting textbooks deal with cross-company EPS comparisons.)
} 
Summary of Calculations:

\begin{tabular}{|l|c|c|}
\multicolumn{2}{|c|}{ ROE } & Company B \\
\hline Net Income & Company A & $\$ 1,500,000=5 \%$ \\
Stockholders' Equity & $\$ 2,500,000=25 \%$ & $\$ 30,000,000$ \\
\hline
\end{tabular}

\begin{tabular}{|l|c|c|}
\hline & Company A & Company B \\
\hline Stockholders' Equity & $\$ 10,000,000=\$ 10$ & $\frac{1,000,000 \text { shares }}{200,00000}=\$ 150$ \\
\# of Common Shares & & shares \\
\hline
\end{tabular}

EPS

\begin{tabular}{|l|c|c|}
\hline & Company A & Company B \\
\hline Net Income & $\$ 2,500,000=\$ 2.50$ & $\$ 1,500,000=\$ 7.50$ \\
\# of Common Shares & $1,000,000$ shares & 200,000 shares \\
\hline
\end{tabular}

The example above illustrates that EPS comparisons should not be made across companies. Company B has a greater EPS than Company A simply because Company B has fewer common shares outstanding and a higher book value per share. EPS has dollars of income (per share) in the numerator divided by an arbitrary number of common shares outstanding in the denominator, making inter-company comparisons meaningless. By contrast, the ROE metric can be compared across companies because both the numerator and the denominator of this ratio are expressed in dollars.

We hope that students at this point understand that EPS comparisons across companies are not meaningful. However, you will want to point out to your students that EPS figures are meaningful when used to track one company's performance over time.

Additionally, EPS is useful as the denominator of the P/E Ratio. Since the numerator of the P/E ratio (fair market value per share) and the denominator (EPS) are both on a per share basis, the number of common shares outstanding does not impact the calculation. In effect, the P/E ratio could be computed as follows: Market Capitalization divided by Net Income and can be safely compared across companies. In this method of calculation, the number of common shares outstanding is not used. In the same way, ROE (net income divided by stockholders' equity) is not impacted by the number of common shares outstanding and can be meaningfully compared across companies.

Students sometimes become confused with why one should avoid making EPS comparisons across companies and yet financial analysts often focus on EPS growth rates across companies. Indeed, while EPS comparisons across companies need to be avoided since the number of common shares outstanding in the denominator is arbitrary, students need to be reminded that EPS is still a valid measure of one company's performance over time. Thus if, for example, the XYZ Company had an EPS of \$2.50 per share in Year 1 and \$3.50 per share in Year 2, we can assert that the XYZ Company is improving. In intermediate accounting courses, students learn how to retroactively restate prior years' EPS figures to reflect stock dividends and stock splits. This allows an analyst to make "apples to apples" EPS comparisons of one company's performance over time and accurate calculations of EPS growth rates for any company being evaluated.

In summary, although one should avoid comparing raw EPS figures across companies, one can make valid inter-company comparisons if, for example, one company's EPS is growing at, let's say, a 3\% snail's pace, while a second company's earnings are growing at a rapid $25 \%$ per year. Since stock prices are largely driven by expectations of future earnings, a strong EPS growth rate may indicate high company value to the extent that past earnings trends are expected to continue.

4. Utilizing your discussion comparing the appropriate usage of EPS and ROE in the prior two questions and the additional ratios computed in the first question, prepare a brief financial analysis report discussing the strengths and weaknesses of Amazon.com versus Barnes \& Noble as of the end of Fiscal 2007. It would 
be useful if your report specifically addressed profitability, solvency, and fair value ratios in separate sections.

In addition to the ratios discussed above you should read the Management's Discussion and Analysis (MD\&A) sections in the 2007 annual reports of Amazon.com and Barnes \& Noble. These annual reports can be found by clicking on "Investor Relations" in the Amazon.com and Barnes \& Noble web sites or by going to the following:

For Amazon.com:

http://media.corporate-ir.net/media_files/irol/97/97664/2007AR.pdf

For Barnes \& Noble:

http://www.barnesandnobleinc.com/for_investors/annual_reports/Barnes \%26_Noble_2007_Annual_Repo $\underline{\text { t.pdf }}$

The conclusion of your report should clearly indicate which company you believe is a better investment as of the end of fiscal 2007 and should include a clear discussion of how the contradictory ROE and EPS information from the two companies impacted your conclusion.

Using the information found in the companies' income statements, balance sheets and statements of cash flows for fiscal 2007, students were previously asked to compute various financial ratios to answer Question 1. Overall, students will likely be impressed that Amazon.com appeared to have stronger profitability and solvency ratios (e.g., greater operating cash flows relative to total liabilities) compared with Barnes \& Noble. Still the very high P/E Ratio of 82.7 for Amazon.com will appear to be quite expensive for students compared with the modestly priced stock of Barnes \& Noble with a P/E Ratio of 16.1.

In the subsections below we share some insights into the profitability, solvency, and fair market value ratios of Amazon.com and Barnes \& Noble (with special attention, when appropriate, to the relative value of comparing ROE and EPS figures across companies). As soon as students realize that they should not compare EPS figures across companies, they should be in a better position to complete the comprehensive financial statement analysis requested in Question 4.

Before we provide some insights on the profitability, solvency, and fair market value ratios for this case, we wanted to suggest something that has worked in our classes. We suggest that you add a comment similar to the one below with the case instructions that you provide to students:

With hindsight students could, of course, look up the change in stock prices for Amazon.com and Barnes \& Noble since the end of fiscal 2007 to see which company turned out to be the better buy subsequent to the release of each company's 2007 annual report (for example, see yahoo.finance.com to look up historical stock prices); however, this is not the assignment. Instead students should focus their discussion on the relative financial strengths and weaknesses of the two companies and answer the narrow technical question of whether or not one can use EPS and/or ROE ratios to compare the financial strengths and weaknesses of two companies.

\section{Profitability Analysis}

Students should be able to see that Amazon.com's greater ROE in 2007 (relative to Barnes \& Noble-$39.8 \%$ versus $12.7 \%$ ) was driven (in part) by Amazon.com's greater profit margin ratio (3.2\% versus $2.5 \%)$ and asset turnover ratio (2.3 versus 1.7 ) leading to a greater return on assets (7.4\% versus $4.3 \%$ ) for Amazon.com compared with Barnes \& Noble (see answer to Question 1).

Any company's profit margin ratio times its asset turnover ratio equals the return on assets for that company. For example, the product of Amazon.com's profit margin ratio of 3.2\% times its asset turnover ratio of 2.3 equals its $7.4 \%$ return on assets ratio. 
Both Amazon.com and Barnes \& Noble were able to increase their return on equity (ROE) through the use of leverage. For example, if one were to multiply Amazon.com's return on assets ratio of $7.4 \%$ by its very high 5.4 leverage ratio the resulting product would be the very impressive ROE of $40.0 \%$ (which is rounded up a bit from the previously calculated 39.8\%). For Barnes \& Noble, its return on assets of $4.3 \%$ times its leverage ratio of 3.0 yields a modest ROE of $12.9 \%$ (which is rounded up a bit from the previously calculated $12.7 \%$ ). Note: The US average return on equity in recent decades has been approximately $15-20 \%$.

Stickney and Weil (2010) assert that the US average for the leverage ratio has historically been about 2.0 (which corresponds to a 50\% debt to assets ratio). Both Amazon.com and Barnes \& Noble use more than the average amount of leverage in an attempt to increase ROE. Unfortunately, there is much risk associated with increasing leverage and in an economic downturn a company with considerable leverage will have a greater risk of bankruptcy as it attempts to pay interest and principal on the company's heavy debt load.

Some students may assume that Amazon.com's greater ROE automatically makes it a better investment than Barnes \& Noble (noting again that Barnes \& Noble's \$2.03 EPS cannot be meaningfully compared with Amazon.com's \$1.12 EPS), but hopefully other students will suggest that solvency and fair market value ratios also need to be considered before an investment decision is made.

Before we turn our attention to the solvency and fair market value ratios of Amazon.com and Barnes \& Noble, we now briefly consider the issue of whether or not it is reasonable to compare EPS growth rates across companies. To try to help guide our students we sometimes direct them to consider the data in Table 3 which shows the sales, net income and EPS for Amazon.com and Barnes \& Noble over the last 5 years. Students will notice that Amazon.com is growing rapidly while Barnes \& Noble has been fairly static by comparison. Over the last 5 years, Amazon.com has seen a $164 \%$ increase in sales, a 1,260\% increase in net income, and a 1,300\% increase in EPS. By contrast over the last 5 years, Barnes \& Noble has experienced a $24 \%$ increase in sales, an $11 \%$ decrease in net income, and a $2 \%$ decrease in net income. At this point, hopefully students will continue to question the value of comparing the relative EPS figures of Amazon.com and Barnes \& Noble. Does it really matter that Barnes \& Noble has a greater EPS than Amazon.com when Barnes \& Noble has such poor sales and earnings growth over the last 5 years? Specifically, students will hopefully see that the higher EPS growth rate and higher ROE for Amazon.com provide support for the market pricing Amazon.com at a much higher multiple of earnings relative to Barnes \& Noble.

In addition to analyzing financial ratios, we suggest that students familiarize themselves with the management's discussion and analysis section of each company's annual report to further be able to explain the change in profitability for each company. These same management's discussion and analysis sections can also be used to gain insights into the relative solvency of each company. In the next section, we consider three solvency ratios that students are asked to compute: the cash debt coverage ratio, the current ratio and the debt to assets ratio.

\section{Solvency Analysis}

The cash debt coverage ratio (i.e., cash provided by operations divided by total liabilities), is an especially important solvency ratio as it is often an excellent indicator of companies on the brink of bankruptcy. Stickney and Weil (2010) assert that most companies fall in the range of $20 \%$ to $40 \%$ on the cash debt coverage ratio. In fiscal 2007, Amazon.com and Barnes \& Noble are safely within the "acceptable" $20 \%$ to $40 \%$ cash debt coverage ratio range. Overall, this ratio does not suggest a solvency problem for Amazon.com or for Barnes \& Noble.

In the solvency section, students should also analyze the current ratio. Amazon.com and Barnes \& Noble have fairly healthy current ratios (1.39 for Amazon.com and 1.21 for Barnes \& Noble), and both are just under the S \& P 500 average of 1.51 as of June 24, 2009 (per the Reuters web site from which benchmark data can be found): http://www.reuters.com/finance/stocks/ratios?symbol=BKS.N. Although both companies' current ratios are below the S \& P 500 average, these ratios for Amazon.com and Barnes \& Noble are greater than 1 to 1 and consistent with other major retailers. 
Stickney and Weil (2010) suggest that most U.S. companies have debt to asset ratios ranging from $40 \%$ to $60 \%$. Amazon.com and Barnes \& Noble both have debt to asset ratios above $60 \%$, which is on the aggressive side. (Amazon.com has an especially aggressive debt to assets ratio of $81.5 \%$.) Students should be asked to consider whether Amazon.com and Barnes \& Noble are carrying an appropriate amount of debt on their respective balance sheets.

At this point in the discussion, we generally review the concept of leverage and how greater use of leverage can increase ROE (but can reduce ROE if a company's return on assets is less than its after-tax cost of borrowing). In general, companies with fairly stable earnings can safely take on more leverage and increase ROE, while companies with less stable earnings should take on less debt and reduce the risk of bankruptcy.

Fair Market Value Analysis

Using the P/E ratio, students should be able to see that Amazon.com stock (with a P/E Ratio of 82.7) is more expensive to purchase than Barnes \& Noble's stock (with a P/E Ratio of 16.1). For some students, Barnes \& Noble's lower stock price (as a multiple of EPS) helps them conclude that Barnes \& Noble is the best stock to buy. On the other hand, some students may argue that Amazon.com is the better investment because of its greater sales and EPS growth rates relative to Barnes \& Noble. At this point in the class discussion, you may want to have a class vote. Should Saint Francis invest in Amazon.com or Barnes \& Noble?

In an introductory Principles of Financial Accounting class at the undergraduate level, students are not usually equipped to delve into forecasting the future earnings/operating cash flows of Amazon.com and Barnes \& Noble. Nor can they use present value techniques to "determine" if each stock is overvalued or undervalued (we probably need to leave this for a finance class). On the other hand, with an MBA financial accounting class (or an undergraduate intermediate accounting class) present values will be a familiar topic and the faculty member has the option to get their MBA financial accounting or intermediate accounting students to estimate the "intrinsic" value of Amazon.com and Barnes \& Noble stock using present value calculations to determine if each stock overvalued or undervalued.

\section{Analysis Conclusion}

Question 4 asks students to conclude their analysis write-up with a discussion as to which company they believed was the better investment as of the end of fiscal 2007. Additionally, students are asked to provide a clear concluding statement as to how the contradictory ROE and EPS information impacted their recommendation.

As to their recommendation of which company is a better investment, our experience shows most students will likely indicate that Amazon.com is the better investment based on the data given in the case. However, there will likely be some differences of opinion. Students who argue that Amazon.com is the better investment will likely focus on this company's greater earnings growth rate and future growth potential. However, students who argue for Barnes \& Noble will likely focus their discussion on this company's lower price to earnings ratio (a "value" stock perhaps) and more conservative use of leverage. We have graded student papers based on the quality of their analysis and their write-up and not on their final recommendation of which stock to purchase.

In the final class discussion on this case we have found that students are very interested in the stock price performance of the two companies since the end of 2007. While not part of the formal assignment we have recently been able to note that Amazon.com's stock price has dropped from about $\$ 94$ to $\$ 84$ and Barnes \& Noble has dropped from about $\$ 32$ to $\$ 22$ since the end of Fiscal 2007. (We would recommend that you update this discussion to reflect the current market prices of the two companies). Obviously in the short run, the purchase of either stock yielded a loss, with the bigger percentage loss being Barnes \& Noble. With the obvious benefit of hindsight, it can be seen that the best short-run decision would have been to invest the donated monies into a low-risk interest bearing security instead of buying stock in either company.

It is difficult to say what will happen with Amazon.com and Barnes \& Noble in the long run. Students may mention that in favor of Amazon.com is the success of Kindle, the rapid growth in Internet book (and CD and DVD etc.) sales, the leadership of CEO Jeff Bezos, and the company's overall dominance of its market. In favor of Barnes $\&$ Noble is the fact that it is not as leveraged as Amazon.com, it dominates the brick and mortar part of the book 
retail industry, and it is more cautious than Amazon.com (not pushing new technologies like Kindle) and may win out in the long run. But generally students are likely to side with Internet icon Amazon.com. Barnes \& Noble may seem too old-fashioned for today's tech savvy students.

As to the impact of ROE and EPS on their recommendation, students will hopefully have etched in memory that ROE figures can be meaningfully used to compare the financial fortunes of two companies, while EPS figures should not be used to compare across two companies since EPS figures are impacted by an arbitrary number of common shares in the denominator of this ratio. Students' conclusions should include a clear statement to this effect.

In our experience, we have found that cases that ask students to make a decision (e.g., buy Amazon.com or Barnes \& Noble stock) generate considerable interest and provide for a meaningful learning experience. Students appreciate the usefulness of accounting information if they can see how the information is used to make a decision.

\section{AUTHOR INFORMATION}

Timothy Kelley, Professor of Accounting, formerly worked with the CPA firm Arthur Andersen \& Co. He received his CPA certificate in 1979. Dr. Kelley has been teaching at the University of San Diego since 1983 and his primary teaching interests are financial and managerial accounting. Most of his research has focused on the impact of time pressures on the work environment of auditors working in public accounting. He has published articles in the following journals: Auditing: A Journal of Practice and Theory, Advances in Accounting, Accounting Horizons, The Journal of Applied Business Research, The CPA Journal, and National Public Accountant.

Judith Hora is an Associate Professor of Accounting at the University of San Diego where she teaches financial accounting in the undergraduate program and financial and international accounting in the graduate programs. Her research focuses on international accounting in capital markets and has been published in a number of academic journals including: The International Journal of Accounting, Journal of International Accounting, Auditing and Taxation, Global Perspectives on Accounting Education, and Journal of College Teaching \& Learning. Dr. Hora is a licensed CPA in the state of Texas.

Loren Margheim, Professor of Accounting, joined the University of San Diego in 1984. He received his CPA certificate in 1979. Dr. Margheim's specialties are in corporate financial reporting and auditing. His research has generally focused on factors affecting the behavior of auditors while performing audits. Specifically, he has performed research that has identified factors that cause auditors to engage in dysfunctional behaviors during their audits. He has also extensively examined how the work performed by a corporation's internal auditors affects the work of their external CPA's. His research papers have appeared in such journals as Journal of Accounting Research, Advances in Accounting, Auditing: A Journal of Theory and Practice, and Accounting Horizons.

\section{REFERENCES}

1. Dyckman, Thomas R., Peter D. Easton, and Glenn M. Pfeiffer. 2007. Financial Accounting. Cambridge Business Publishers. Westmont, Illinois.

2. $\quad$ Easton, Peter D., John J. Wild, and Robert F. Halsey. 2006. Financial Accounting forMBAs ( $2^{\text {nd }}$ ed.). Cambridge Business Publishers. Westmont, Illinois.

3. Harrison, Walter T., Charles Horngren, and William Thomas. 2010. Financial Accounting ( ${ }^{\text {th }}$ ed.). Pearson Education, Inc., Upper Saddle River, New Jersey.

4. Kelley, Tim and Judith Hora. 2008. The folly of making EPS comparisons across companies: Do accounting textbooks send the correct message?" The Journal of College Teaching and Learning. 5 (2): 5360.

5. Kimmel, Paul D., Jerry, J. Weygandt, and Donald E. Kieso. 2009. Financial Accounting: Tools for Business Decision Making ( $5^{\text {th }}$ ed.). John Wiley \& Sons, Hoboken, New Jersey.

6. Needles, Belverd E. and Marian Powers. 2007. Financial Accounting ( $9^{\text {th }}$ ed.). Houghton Mifflin Company, Boston.

7. Stickney, Clyde P., Roman L., Weil, Katherine Schipper, and Jennifer Francis. 2010. Financial Accounting: An Introduction to Concepts, Methods, and Uses (1 $1^{\text {th }}$ ed.). South-Western, Mason, Ohio. 